\title{
KRITIK PADA PENELITIAN KUALITATIF
}

\author{
Junaiti Sahar*
}

\begin{abstract}
Abstrak
Penelitian merupakan proses menjawab keingintahuan dengan menjawab pertanyaan atau menyelesaikan masalah. Artikel ini ditujukan untuk memberikan wawasan kepada pembaca bagaimana melakukan telaahan hasil penelitian melalui kritik penelitian. Penelitian dilakukan melalui tahapan sistematis dan dilaporkan secara jelas dan terinci. Laporan dan atau artikel suatu penelitian dianggap layak untuk diimplementasikan apabila hasilnya telah melalui proses pengujian yang teliti dan mendalam, yang disebut kritik penelitian. Kritik penelitian dapat dilakukan dengan menggunakan sepuluh elemen dan kriteria yang telah dirumuskan para ahli penelitian kualitatif. Kesepuluh elemen tersebut mencakup: topik, tujuan, disain atau pendekatan, deskripsi informan/ partisipan, metode pengumpulan data, metode analisis data, hasil penelitian, simpulan, dan rekomendasi. Setiap elemen memiliki kriteria sebagai indikator. Kebenaran laporan penelitian atau artikel perlu ditelaah dengan teliti dan kritis untuk mendapatkan pemahaman yang luas, menetapkan fakta yang dapat digunakan dalam praktik, dan sebagai dasar penelitian berikutnya.
\end{abstract}

Kata kunci: Kritik, research, kualitatif, kritik penelitian

\begin{abstract}
Research is a method to answer questions or to solve problems. This article addresses to enrich the readers how ro review a research report through critique research. Research is conducted by a systematic set of procedures and steps and to be clearly and detail reported. Report and/ or article resulted from a research will be considerably feasible implemented whenever the result of study has been reviewed through an accurate and deepen process of assessment or examination which is called critique research. Critique research can be taken by using ten elements and criteria formulated by qualitative research experts. The ten elements include: topic, purpose, design or approach, informant/ participant description, method of data collection, data analysis, findings, conclusion and recommendation. Each element has criteria as an indicator. Therefore, the authenticity of the research report and or articles need to be assessed by careful critical analysis as to broaden the understanding, determine evidence for use in practice and provide a background for conducting further research study.
\end{abstract}

Key words: Critique, Research, Qualitative, Critiquing research

\section{PENDAHULUAN}

Penelitian merupakan upaya untuk menemukan jawaban terhadap keingintahuan peneliti terhadap suatu fenomena baik secara induktif maupun deduktif. Upaya untuk menemukan jawaban yang dilakukan secara induktif lazim dilakukan oleh peneliti kualitatif.

Metode ini juga disebut postpositivistik dan interpretive serta bersifat natural. Dikatakan postpositivistik karena didasarkan pada filsafat postpositivisme yakni memandang realitas sosial sebagai suatu yang holistik, kompleks, dinamis, penuh makna dan hubungan bersifat interaktif (Sugiyono, 2009).

Lebih lanjut penulis juga mengemukakan bahwa disebut interpretive karena hasil penelitian sangat terkait dengan interpretasi data temuan di lapangan dan pada kondisi yang alamiah. Penelitian kualitatif juga bersifat lokal spesifik, sehingga tidak dapat digeneralisasikan seperti penelitian kuantitatif.

Pendekatan kualitatif mencoba mengeksplorasi, menemukan, menguraikan dan menjelaskan kualitas atau keistimewaan suatu realitas sosial yang tidak dapat didefinisi secara jelas, diukur, dan dihitung. Keistimewaan ini mencakup nilai, keyakinan, makna bahasa dan persepsi yang dimiliki seseorang tentang pengalamannya (Streutbert \& Carpenter, 1999).

Beberapa asumsi yang melandasi penelitian kualitatif yakni realitas, hubungan dan kebenaran pernyataan yang alamiah. Realitas yang alamiah dimaknai sebagai fenomena sosial yang abstrak, dinamis dan kontekstual. 
Hubungan yang alamiah dimaknai sebagai individu peneliti dipandang sebagai sesuatu yang berada diluar proses penelitian yang perlu dikontrol dan peneliti dianggap sebagai instrumen penelitian. Sedangkan kebenaran pernyataan yang alamiah merupakan realitas yang dapat diprediksi, dinamis dan selalu berubah-ubah (Creswell, 1998; Streutbert \& Carpenter, 1999). Peneliti kualitatif juga memberikan pembenaran bahwa sesuatu yang mustahil untuk memisahkan konteks atau tatanan dimana fenomena itu terjadi dengan fenomena itu sendiri (Lee, 2006), berarti keduanya saling terkait dan memberi makna tertentu yang perlu diinterpretasikan.

Peneliti perlu memahami asumsi-asumsi tersebut sebagai landasan filosofis pentingnya pendekatan kualitatif pada suatu penelitian. Selain itu, pertanyaan penelitian juga perlu dirumuskan secara jelas dan tepat. Pertanyaan penelitian kualitatif dirumuskan untuk menjawab pertanyaan terhadap suatu realitas sosial (fenomena) mencakup apa yang terjadi, bagaimana sesuatu bisa terjadi, apa konteksnya, apa yang penting, kenapa penting, dan apa saja variasi yang ditemukan pada fenomen tersebut.

Penelitian kualitatif belum banyak digunakan dalam bidang kesehatan khususnya keperawatan. Karena pendekatan ini relatif baru digunakan dalam keperawatan di Indonsesia. Pendekatan ini dianggap abstrak dan subjektif, lebih banyak digunakan untuk mengeksplorasi fenomena sosial termasuk segala sesuatu yang menyangkut perilaku manusia.

Padahal pendekatan ini sangat relevan dengan fenomena keperawatan yakni mengeksplorasi kebutuhan dasar manusia, yang tentu sangat erat kaitannya dengan respons manusia dalam hal ini sistem klien baik individu, keluarga, kelompok dan masyarakat. Karena tidak semua respons manusia dapat dikuantifikasi, bersifat dinamis dan kontekstual. Oleh karena itu, peneliti atau calon peneliti perlu memahami elemen atau komponen yang harus ada dalam suatu studi atau artikel penelitian kualitatif.

Setiap elemen suatu studi atau artikel riset kualitatif perlu ditelaah secara tajam untuk dapat menilai hasil studi atau artikel tersebut layak diimplementasikan. Elemen yang perlu ditelaah antara lain: Topik harus tepat untuk menjawab keingintahuan secara kualitatif; tujuan dinyatakan secara jelas; disain atau pendekatan kualitatif yang dipilih harus sesuai dengan tujuan penelitian; deskripsi yang luas terhadap informan dan konteksnya; metode yang tepat untuk mengumpulkan data; kejelasan tentang metode analisis data, pembahasan hasil, simpulan dan rekomendasi; serta adanya pernyataan tentang relevansi dan pentingnya hasil penelitian (Forchuk \& Roberts, 1993), untuk praktik keperawatan dan penelitian berikutnya. Adapun tujuan penulisan ini adalah memberikan gambaran tentang pengertian kritik, tujuan, elemen atau kriteria kritik penelitian kualitatif yang perlu ditelaah, sehingga dapat dijadikan acuan oleh mahasiswa dan dosen untuk melakukan penilaian terhadap laporan atau artikel hasil penelitian kualitatif.

\section{PEMBAHASAN}

Pembahasan artikel ini memuat pengertian tentang kritik penelitian, tujuan kritik penelitian, tahapan, elemen dan kriteria kritik penelitian

Kritik penelitian mengandung beberapa pengertian. Kritik penelitian adalah menilai dengan teliti terhadap kekuatan dan kelemahan suatu studi. Kritik penelitian intelektual adalah juga memeriksa dengan teliti dan menyeluruh selain dengan mempertimbangkan kekuatan, kelemahan, namun juga keterkaitan logika, arti dan kemaknaan suatu studi; dan proses evaluasi yang dilakukan secara objektif dan kritis terhadap isi laporan penelitian digunakan sebagai kajian ilmiah dan aplikasi pada praktik, teori serta pendidikan.

Adapun tujuan dari kritik penelitian ini adalah memberi masukan terhadap suatu laporan atau artikel hasil penelitian. Masukan ini penting untuk dipertimbangkan dalam rangka melanjutkan penelitian berikutnya atau implementasi hasil penelitian.

Menurut Wood dan Haber (2002) tahapan melakukan kritik penelitian adalah sebagai berikut: (1) Baca dan kritik secara keseluruhan isi suatu studi. Kritik mencakup kualitas dari seluruh tahapan proses penilitian; (2) Periksa pengorganisasian dan tampilan laporan atau artikel penelitian. Laporan atau artikel yang dipersiapkan dengan baik artinya adalah lengkap, ringkas dan padat, disajikan dengan jelas, serta diorganisasi secara logis. Tulisannya tidak banyak jargon yang dapat menyulitkan pembaca mahasiswa atau praktisi keperawatan. 
Kemudian daftar rujukan ditulis lengkap dan sistematis susuai aturan; (3) Periksa makna masalah penelitian untuk praktik keperawatan. Fokus studi keperawatan haruslah terkait dengan masalah dalam praktik, jika tentang pengetahuan maka seharusnya yang mendasari pengembangan profesi; (4) Identifikasi kekuatan dan kelemahan studi tersebut. Semua studi memiliki kekuatan dan keterbatasan, sehingga perhatian perlu diberikan pada semua aspek tersebut; (5) Dalam mengidentifikasi kekuatan dan keterbatasan lakukan secara objektif dan realistik. Kritiklah secara adil dan hindari tumpang tindih dalam menilai kekuatan dan kelemahan tersebut; (6) Berikan contoh kekuatan dan keterbatasan dari studi yang dikritik. Sebagai contoh tampilkan fakta dalam mengkritik kekuatan dan keterbatasan suatu studi; (7) Berikan pembenaran atau rasional untuk kritik yang dilakukan terkait kekuatan dan keterbatasan; (8) Sarankan modifikasi untuk studi berikutnya. Modifikasi untuk studiberikutnya akan meningkatkan kekuatan dan meminimalkan keterbatasan studi; (9) Diskusikan kemungkinan replikasi studi. Apakah studi yang ditampilkan cukup rinci untuk direplikasi; dan (10) Diskusikan kegunaan hasil penelitian untuk praktik. Hasil dari suatu studi perlu dikaitkan dengan hasil studi sebelumnya. Semua hasil studi perlu ditelaah keterkaitannya dengan praktik klinik.

Tahapan kiritik penelitian tersebut dilakukan secara sistematis dengan menggunakan elemen dan kriteria sebagai indikator penilaian untuk setiap elemen.

\section{Elemen dan Kriteria Kritik Penelitian}

Berikut ini akan diuraikan elemen dan kriteria kiritik penelitian kualitatif secara umum yang merupakan sintesis dari pendapat para ahli (Streuber \& Carpenter, 1999; Lee, 2006; Sugiyono, 2009; Law,M, 1998; dan Forchuk \& Roberts, 1993) sebagai berikut:

\section{JUDUL}

Judul atau topik pada penelitian kualitatif menggambarkan usaha untuk mengungkapkan fenomena dalam situasi sosial secara luas dan mendalam, misalnya: "Pengalaman klien menerima terapi yang berbeda untuk hipertensi". Judul menggambarkan pengaman informan dalam menjalani terapi untuk menurunan tekanan darah.
Diharapkan dengan judul ini peneliti dapat mengeksplorasi secara luas dan mendalam untuk memperoleh makna yang dalam dan dapat dinterpretasikan sebagai hasil penelitian.

Kriteria kritik: Apakah judul penelitian yang diajukan peneliti menggambarkan fenomena yang menjadiminat?

\section{PERNYATAAN TENTANG FENOMENA YANG DIMINATI}

Fenomena yang menjadi minat peneliti harus dijelaskan secara rinci dan sistematis. Beberapa teori dan hasil penelitian sebelumnya yang relevan dengan fenomena yang diminati perlu didiskusikan secara jelas. Ditunjang pula dengan penjelasan tentang alasan filosofis kenapa metode kualitatif tertentu dipilih untuk studi dan alasan pendekatan kualitatif yang dipilih juga perlu dijelaskan.

Kriteria kritik:

a. Apakah fenomena yang menjadi minat diidentifikasi secara jelas?

b. Apakah peneliti telah mengidentifikasi kenapa penelitian tersebut memerlukan metodologi kualitatif?

c. Apakah peneliti telah menjelaskan alasan filosofis yang melandasi penelitian?

\section{TUJUAN DAN MANFAAT PENELITIAN}

Suatu penelitian perlu mendeskripsikan tujuan penelitian secara jelas yang dapat memberikan arah pada penelitian yang dilakukan. Tujuan penelitian ini dapat menggambarkan pendekatan penelitian kualitatif yang dipilih. Sebagai contoh, jika peneliti ingin melakukan studi fenomenologi, maka rumusan tujuan yang dituliskan menggambarkan "arti dan makna pengalaman partisipan", Jika studi etnografi yang dipilih, tujuan menggambarkan kultur atau konteks budaya yang akan diteliti.

Sedang grounded theory, tujuan penelitian menggambarkan teoribaru yang akan dihasilkan. Secara singkat peneliti juga perlu menuliskan kemaknaan atau manfaat hasil penelitian untuk praktik keperawatan. Sehingga penelitian yang dilakukan dapat berdampak terhadap praktik keperawatan. 
Sebaliknya praktik keperawatan yang berkualitas perlu didasari oleh hasil penelitian yang baik.

Kriteria kritik:

a. Apakah peneliti telah menjelaskan secara eksplisit tujuan penelitian dilakukan?

b. Apakah penelitimenggambarkan kemaknaan atau manfaat penelitian untuk praktik keperawatan?

\section{DISAIN ATAU PENDEKATAN}

Disain atau pendekatan penelitian kualitatif yang dipilih harus relevan dengan tujuan penelitian. Misalnya pada penelitian dengan judul: "Pengalaman klien menerima terapi hipertensi yang berbeda".

Topik ini memberikan keleluasaan bagi peneliti mengikuti secara langsung dalam kehidupan seharihari klien hipertensi sesuai konteks budaya klien (etnografi); menggali pemahaman klien tentang perbedaan terapi dan mengembangkan teori sebagai hasil riset (grounded theory); dan menggali pengalaman hidup klien hipertensi (fenomenologi). Ketiga pendekatan ini lazim digunakan dalam penelitian kualitatif.

Kriteria kritik:

a. Apakah disain yang dipilih sesuai atau relevan dengan tujuan penelitian?

b. Apakah disain yang dipilih adekuat untuk menjelaskan fenomena yang diminati?

c. Apakah disain atau pendekatan kualitatif tertentu (fenomenologi atau etnografi atau grounded theory) yang digunakan untuk menuntun penelitian?

d. Apakah peneliti telah menyelesaikan studi sesuai proses atau tahapan pendekatan kualitatif yang dipilih?

\section{STRATEGI PEMILIHAN SAMPEL}

Pada penelitian kualitatif pemilihan sampel yang lazim digunakan adalah purposive sampling dan snowball sampling. Kedua metode ini termasuk non probability yang artinya pemilihan sampel tidak memberikan kesempatan yang sama pada populasi untuk dipilih. Purposive sampling artinya sampel dipilih sesuai keinginan peneliti atas dasar pertimbangan tertentu dan sesuai kriteria yang ditetapkan, antara lain sampel haruslah memiliki kemampuan berbahasa dengan baik dan memiliki pengetahuan yang memadai tentang fenomena yang menjadi minat peneliti.

Sedangkan Snowball sampling teknik pengambilan sampel yang mengacu pada sumber data, yang pada awalnya jumlah sampel sedikit, lama-lama jumlahnya menjadi besar. Jumlah sampel juga ditentukan berdasarkan kejenuhan atau saturasi data.

\section{Kriteria kritik:}

a. Apakah peneliti menjelaskan cara pemilihan sampel?

b. Apakah peneliti telah menjelaskan jumlah sampel setelah terjadi saturasi data?

c. Apakah informan atau partisipan yang dipilih tepat untuk menginformasikan penelitan?

\section{PENGUMPULAN DATA}

Berbagai metode yang dapat dipilih untuk penelitian kualitatif diantaranya wawancara mendalam, diskusi kelompok terfokus, observasi, narasi tertulis, dokumentasi, catatan lapangan. Metode ini hendaklah dipilih sesuai tujuan penelitian dan pendekatan kualitatif yang dipilih.

Prosedur pengumpulan data dituliskan secara eksplisit. Selain itu, peneliti pun perlu menuliskan perlindungan terhadap informan atau partisipan sesuai prinsip dasar etik penelitian otonomi, kemanfaatan, dan keadilan.

Kadangkala tidak semua peneliti menuliskan secara rinci tahapan tersebut pada artikel jurnal, hal ini karena terbatasnya jumlah kata dan kalimat yang dipersyaratkan sebuah jurnal.

\section{Kriteria kritik:}

a. Apalah pengumpulan data difokuskan pada pengalaman manusia?

b. Apakah peneliti menjelaskan metode pengumpulan data yang dipilih?

c. Apakah peneliti menuliskan perlindungan terhadap partisipan atau informan?

d. Apakah peneliti menuliskan tahapan atau prosedur pengumpulan data?

e. Apakah saturasi/kejenuhan data dijelaskan? 


\section{ANALISIS DATA}

Proses analisis data pada penelitian kualitatif dilakukan secara induktif. Beberapa metode analisis data dapat digunakan sesuai pendekatan penelitian kualitatif yangdigunakan. Sehingga peneliti perlu menjelaskan metode analisis data yang dipilih dan alasan memilih metode tersebut yang relevan dengan tujuan penelitian. Tahapan proses analisis data yakni bagaimana tema dirumuskan berdasarkan subtema, sub-sub tema, kategori dan kata kunci perlu dijelaskan secara rinci.

Kriteria kritik:

a. Apakah peneliti menjelaskan metode atau strategi analisis data yang dipilih?

b. Apakah pembaca memahami metode apa yang digunakan untuk melakukan analisis data?

c. Apakah metode atau strategi analisis data sesuai dengan tujuan penelitian?

\section{KEABSAHAN DATA}

Uji keabsahan data pada penelitian kualitatif terdiri atas uji: credibilily; auditability; dan fittingness. Uji credibility disebut juga sebagai uji validitas internal. Uji ini dilakukan dengan mengembalikan data yang telah diverbatim atau data yang telah diklasifikasikan sesuai kata kunci dan kategori berikut rekamannya kepada informan atau partisipan. Bila setelah diperiksa kembali pada informan data sudah sesuai atau benar, maka data tersebut kredibel. Auditability disebut juga uji reliabilitas.

Hasil penelitian perlu diaudit oleh auditor independen atau pembimbing untuk mengaudit keseluruhan proses atau tahapan penelitian mulai dari menentukan masalah sampai membuat kesimpulan harus dapat ditunjukkan atau dijelaskan peneliti. Apabila peneliti mampu menunjukan rekam jejak tahapan yang dilakukan benar, maka dapat dikatakan auditable, dan sebaliknya. Fittingness (kesesuaian) atau disebut juga transferability.

Nilai kesesuaian ini dikaitkan dengan pernyataan hingga mana penelitian ini dapat digunakan pada situasi yang lain. Oleh karena itu peneliti perlu membuat laporan penelitian secara rinci, jelas, sistematis dan dapat dipercaya sehingga pembaca dapat memahami dan mengikuti alur pikir peneliti serta dapat memutuskan apakah penelitian tersebut dapat diaplikasikan pada situasi lain atau tidak.

Kriteria kritik:

Apakah peneliti menjelaskan tentang keabsahan data yang mencakup Credibility, Auditability, dan Fittingness?

a. Credibility: Apakah informan atau partisipan mengingat pengalaman yang dialaminya sendiri?

b. Auditability:

- Apakah pembaca dapat mengikuti alur pikir peneliti?

- Apakah peneliti telah mendokumentasikan proses penelitian?

c. Fittingness?

- Dapatkah hasil penelitian diaplikasikan pada situasi yang berbeda dengan penelitian?

- Apakah hasil penelitian bermakna untuk individu yang tidak berperan serta dalam penelitian?

\section{HASIL PENELITIAN}

Hasil penelitian disusun secara sistematis dan ditampilkan sesuai tujuan khusus yang ditetapkan. Satu tujuan khusus dapat dijawab melalui lebih dari satu tema. Selanjutnya setiap tema diuraikan berdasarkan sub tema dan atau sub-sub tema, kategori serta didukung oleh kata kunci yang relevan. Selanjutnya setiap tema dan sub tema tersebut dihubungkan dengan teori dan hasil penelitian sebelumnya guna menginterpretasikan hasil penelitian yang ditemukan.

Kriteria kritik:

a. Apakah hasil disajikan dalam konteks penelitian?

b. Apakah pembaca mampu memahami esensi dari pengalaman dari hasil penelitian yang dilaporkan?

c. Sudahkan peneliti mengkonsepsualisasikan data dengan benar?

d. Sudahkan peneliti menempatkan laporan hasil penelitian dalam konteks apa yang telah diketahui tentang fenomena tersebut sebelumnya? 


\section{SIMPULAN, IMPLIKASI, DAN REKOMENDASI}

Simpulan haruslah konsisten dan sejalan dengan hasil dan pembahasan yang dilakukan peneliti, bermakna untuk pembaca serta dapat membantu pembaca untuk memahami fenomena yang dieksplorasi dan atau teori yang dihasilkan. Implikasi dan rekomendasi haruslah dituliskan secara jelas dan rinci dikatkan dengan kegunaannya dan atau kebijakan yang akan diambil, khususnya untuk praktik dan penelitian keperawatan berikutnya.

Kriteria kritik:

a. Apakah peneliti mengajukan simpulan, implikasi dan rekomendasi dalam konteks bagaimana hasil penelitian digunakan?

b. Apakah simpulan sudah merefleksikan hasil penelitian?

c. Apakah peneliti sudah memberikan rekomendasi untuk studi lanjutan?

d. Sudahkah peneliti menuliskan secara eksplisit kemaknaan studi terhadap keperawatan?

\section{KESIMPULAN}

Tahapan melakukan kritik penelitian kualitatif perlu dilakukan peneliti dengan menelaah setiap elemen penelitian kualitatif. Sepuluh elemen berikut kriteria perlu ditelaah secara mendalam dan teliti untuk dapat memberikan pembenaran apakah suatu laporan atau artikel suatu studi layak diimplementasikan ke dalam praktik keperawatan atau tidak.

Kritik penelitian ini juga dapat dijadikan acuan untuk menilai hasil suatu studi yang berkualitas atau tidak. Ketrampilan ini perlu dilatihkan kepada mahasiswa atau calon peneliti keperawatan dengan memberikan penugasan atau latihan.
Apabila mereka mampu melakukan telaahan yang baik terhadap suatu artikel kualitatif, maka mereka diharapkan mampu untuk menulis laporan atau artikel penelitian kualitiatif yang baik pula (TN, INR).

* StafAkademik Keilmuan Keperawatan Komunitas FIK UI, Depok

\section{KEPUSTAKAAN}

Cresswell, J.W. (1998). Qualitative inquiry \& research design: Choosing among five traditions. Thousand Oaks: SAGE Publication.

Forchuck, C., \& Roberts, J. (1993). How to critique qualitative research articles. Canadian Journal of Reseach, 25(4): 47-55.

Law, M. et al. (1998). Guidelines for critical review form-Qualitative studies. Diperoleh dari http://fhs.mcmaster.ca/rehab/ebp/pdf/ qualguideline.pdf.

Lee, P. (2006). Understanding and Critiquing qualitative research papers. Nursing Times, 102 (29): 30. Diperoleh dari http://www. nursingtimes.net/nursing-practice-clinicalreserach/understanding-and-critiquing.

Streubert, H.J., \& Carpenter, D.R. (1999). Qualitative research in nursing: Advancing the humanistic imperative (2nd Edition. Philadelphia: Lippincott.

Sugiyono. (2009). Metode penelitian kuantitatif dan kualitatif dan $R \& D$. Bandung: Alfabeta.

Wood, G.L., \& Haber, J. (2002). Nursing research methods, critical appraisal and utilization (5th Edition). St Louis: Mosby.

Orang yang berhasil akan mengambil manfaat dari kesalahan-kesalahan yang ia lakukan, dan akan mencoba kembali untuk melakukan suatu cara yang berbeda.

- Dale Carnegie - 
Tabel 1. Contoh Format Kritik Riset Kualitatif

\begin{tabular}{l} 
No Elemen dan Kriteria \\
\hline 1. Topik/hudul: \\
Apakah judul penelitian yang diajukan peneliti menggambarkan fenomena \\
yang menjadi minat? \\
2. Pemyataan tentang fenomena yang diminati (interest): \\
a. Apakah fenomena yang menjadi minat diidentifikasi secara jelas? \\
b. Apakah peneliti telah mengidentifikasi kenapa penelitian tersebut \\
memerhkan format lualitatif? \\
c. Apakah peneliti telah menjelaskan alasan filosofis yang melandasi \\
Tujuan dan manfaat: \\
a. Apakah peneliti telah menjelaskan secara eksplis it tujuan penelitian \\
b. Apakukan? \\
untuk praktik keperawatan?
\end{tabular}

4. Dis ain atau pendelatam

a. Apakah disain atan pendekatan kualitatif yang dipilih sesuai atan relevan dengan tujuan penelitian?

b. Apakah disain atan pendekatan kualitatif yang dipilih adelonat untuk menjelas kan fenomena yang diminati?

c. Apakah pendekatan kualitatif tertertu (fenomenologi atan etrografi atan grounded theory) yang digunakan untuk meruntum perelitian?

d. Apakah peneliti telah menyeles aikan studi sesuai proses atau tahapan pendekatan kualitatif yang dipilin?

5. Strategi perrilihan sampel:

a. Apakah peneliti menjelaskan cara pernilihan sampel?

b. Apakah peneliti telah merjelaskan jumlah s ampel setelah terjadi saturasi data?

c. Apakah infoman atau partisipan yarg dipilin tepat untuk menginformasikan penelitan?

6. Pengumpulan data:

a. Apalah pengumpulam data difokuskan pada pengalaman marus ia?

b. Apakah peneliti menjelaskan metode pengumpulan data yarg dipilik?

c. Apakah pereliti mernuliskan perlindungan terhadap partisipan atan informan?

d. Apakah peneliti merulis kan tahapan atau prosedur pengumpulan data?

e. Apakahs saturasidata dijelas kan?

7. Analisis data:

a. Apakah peneliti menjelaskam metode atan strategi analisis data yang dipilith?

b. Apakah pembaca memahari metode apa yang digunakan untuk melakukan analisis data?

c. Apakah metode atau strategi analisis data sesuai dengan tujuan penelitian?

8. Keabsahandata:

a. Credibility. Apakah informan atan partisipan mengingat pengalaman yang dialaminya sendiri?

b. Auditability:

- A pakah pemb aca dapat mengikuti alur pikir peneliti?

- A pakah peneliti telah mendolumentasikan proses penelitian?

c. Fittingness:

- Dapatkah hasil penelitian diaplikasikan pada situasi yang berbeda denzan perelitian?

- Apakah hasil penelitian bermakna untuk individu yang tidak berperan serta dalam penelitian?

9. Hasil penelitian:

a. Apakah hasildisajikan dalam korteks penelitian?

b. Apakah pembaca mampu memahami esensi dari pengalaman dari hasil penelitian yang dilaporkan?

c. Sudahkan peneliti mengkonsepsualisas ikan data dengan benar?

d. Sudakkan peneliti menempatkan laporan hasil penelitian dalam kontels apa yang telah diketalui tentang fenomena tersebut sebehimrya?

10. Simpulan, Implikasi dan Rekomendasi:

a. Apakah peneliti mengajukan simpulamimplikasi dan rekomendasi dalam kontels bagaimana hasil penelitian digunakan?

b. Apakahsimpulan sudah merefleksikan hasil penelitian?

c. Apakah peneliti sudah memberikan rekomend asi untuk s tudi lanjutan?

d. Sudahkah peneliti meroliskan secara eksplisit kemaknaan studi terhadap keperawatan?

Total Nilai

Bobot Nilai

5 